\title{
Beyond Stability vs. Change Dilemma: Everyday Practices and Routines as Sources of Organizational Life
}

\author{
Zofia Patora-Wysocka
}

\begin{abstract}
A B S T R A C T
Objective: The aim of this paper is to present the problem of everyday organizational practices and routines as loci of organizational persistence, novelty and transformation. Base on qualitative research the article argue that that spontaneous actions are important factors that introduce organizational change.

Research Design \& Methods: The article presents results of a comparative case study. The methodological choice included interviews and non-participant observation. Sample selection was purposive. The enterprises were selected from creative and textile-apparel industries.
\end{abstract}

Findings: The research illustrates how entrepreneurs respond to everyday phenomena and unplanned situations that co-create their business reality. It turns out that the way of practice reproduction may be of twofold nature: radical and spontaneous or evolution-like and emergent.

Implications \& Recommendations: Perceiving organizations through day-to-day processes offers an opportunity to understand the concept of organizational change. The field of practice theory is open to more management issues.

Contribution \& Value Added: Elaborating on the practice-based view within organization studies, the concept of everyday practices and routines offers a promising approach within change management.

\footnotetext{
Article type: research paper

Keywords:

actions; organizational routines; practice-based study; processual approach; organizational change
}

JEL codes: L20, L21, L26

Received: 15 August 2016 Revised: 17 January 2017 Accepted: 1 February 2017

\section{Suggested citation:}

Patora-Wysocka, Z. (2017). Beyond Stability vs. Change Dilemma: Everyday Practices and Routines as Sources of Organizational Life. Entrepreneurial Business and Economics Review, 5(1), 201-212, DOI: http://dx.doi.org/10.15678/EBER.2017.050112 


\section{INTRODUCTION}

The field of the Practice Turn in management grew out of a concern for locating organization within the texture of everyday practices and routines. The business world involves a continuous flow of human activities, situations, resources, services, commodities and artefacts. Organizational change is thus experienced by entrepreneurs and managers on a daily basis. Business practitioners respond to these everyday phenomena in a routine, spontaneous and unplanned manner. In fact, this is the way the organizational life takes place most of the time. However, organization studies tend to be still affected by the dominant discourse within the management theory, which views enterprises as structures regulated by systemic mechanisms focused on increasing the organization's effectiveness. Explanations of processes are often based on striving after objective, universal, and quantifiable truth. Such an approach "gives ontological priority to the organization (...) as a context for action and thinking" (Hernes, 2014, p. 13). The processual stream of thought in management places more emphasis on getting to know how the organization operates in a turbulent markets. Unlike the dominant approach, it assumes that the actions are what make the organization (Hernes, 2014, p. 13). Thus, it can be assumed that exploration of processual categories of change can contribute to understanding organizational reality. The aim of this paper is to present the concept of everyday organizational practices and routines as loci of organizational persistence, novelty and transformation. The thesis, illustrated with case study research, posits that routines are important factors that introduce organizational change.

The article consists of two parts: theoretical and empirical. The theoretical part shows the practice view on the organization and organizational phenomena. It explores issues mainly related to everyday practices and routines. The empirical part is based on case study research into organizations operating in the textile and apparel industry.

\section{LITERATURE REVIEW}

\section{Routines and Daily Practices: when Unwanted Categories Become Basic Units of Organizational Analysis}

For a long time routines occupied an inglorious position of a "black box" within the organization and management theory (Howard-Grenville, Rerup, Langley \& Tsoukas, 2016; Salvato \& Rerup, 2011). This infamous phrase has become a kind of a denotative expression in recent literature on organizational routines.

In fact, routines used to be almost invisible categories in organizational research. Their existence was knowable a priori in the dominant economic discourse in management. Hence, organizational routines were persistent and "somehow innate" in an organizational structure, and therefore the purposes of research lied behind of routines. The management theory that springs from functionalism and radical structuralism is mainly aimed at observing a system and its effectiveness (Kociatkiewicz \& Kostera, 2013). The deterministic way of thinking developed a series of conceptions that strive as being predictive, general and objectivistic. This line of understanding was present even in the works of Nelson and Winter (1982), who put a milestone in a process orientation and routine dynamics. However, management and organization indulge in day-to-day human 
activities. If daily performances and routines are used as viewpoints on organizational processes, one can find the explanation of how that life is carried out. Observing mundane organizational problems requires a careful methodological choice. In the literature, it is denoted as practice-based study (Gherardi, 2012). In disciplinary terms, practice perspective is constituted. Its purpose, however, is not to neglect the legacy of the dominant thought. Instead, it offers the lenses of practice, micro-ontology, routines, and daily activities etc. Kociatkiewicz and Kostera (2013, p. 13) consider humanistic methodology from the perspective of a wide array of "action research aimed at education and improving the fate of an individual in an organization". I believe that the Practice Turn can be put under the umbrella perspective of humanistic management.

The practice-based orientation focuses on observing organization and management "thrown into everydayness" (Heidegger, 1962). Using the phrase of Tor Hernes, it is not aimed at "comparing states of being in time or space. It is about how something persists and changes in view of becoming otherwise possible" (Hernes, 2014, p. 3). It is about perceiving organization and management through minute details of the way resources, tools, technology, knowledge and human relations are used. Thus, reviewing different lines of theoretical contribution to the practice approach in management, one sees that there is a clear agreement in terms of crucial inner categories of practice, i.e.: actions, daily routines, human individuals, norms and rule-governed activities, goals, artefacts, symbols, discourses, understanding, situatedness and embeddedness etc. (Gherardi, 2015; Guzman, 2013). Thus, organization cannot be understood separately from doing. As Parmigiani and Howard-Grenville (2011, p. 443) note, this is a basis for a critical path within the processual perspective on routines: "perhaps somewhat ironically, studies from the practice (process) perspective are so concerned with situated action - specific actions of specific people in specific organizations" - that they may overlook the organization itself. I believe that observing routines in the realm of everyday organizational life may lead to research awareness. Routines produce, preserve and are at the core of change of each and every aspect of management i.e.: decision-making processes, work coordination, acquiring and distribution of power, and resource allocation. Gherardi adds here "working, learning, innovating, communication, negotiation, conflict over goals, their interpretation, and (organizational) history" (Gherardi, 2012, p. 200). Routines are performed and recreated in a given context and they may overlap across organizations, professions and industries. Howard-Grenville (2005) develops here a wide spectrum of organizational and market categories such as "cultures, hierarchies and technologies" (Howard-Grenville, 2005, p. 619). Feldman and Pentland (2003, p. 95) in their early works assumed that routines are "repetitive, recognizable patterns of interdependent actions, carried out by multiple actors". Further studies of these authors put forward different approach to a problem by focusing on performative and ostensive aspects of routines. According to Feldman and Pentland view procedural way of reproducing routines collides with ostensive aspects of everyday performance. A key question in this view "is the nature of the relation between actions and patterns" (Feldman, 2016 , p. 25). In the centre of this view stands the problem of the way the activity is performed and changed, not the agential forces of its accomplishment (i.e. its collective or individual character). Elaborating on this concept one may see that individuals and sub-systems interact on a daily basis to create and recreate everyday practice. 
Routines may extend beyond organizations and institutions. They are reproduced by individuals as well as organized groups and they can diffuse through various levels of the organisational structures. Mechanisms of everyday reproduction assume not only stability, but also changeability of routines. The cognitive psychology perspective deems activities derived from explicit knowledge to be performed automatically (Beck, 1976). However, they may be changed if they are affected by human reflexivity. People act as agential forces of routine change (Sewell, 1992). People in organizations have the ability to make a cognitive effort, to assess the situation, and to modify the way the activity is performed. Lazaric (2010) uses this idea issue to furnish the theoretical presentation of the process of routine change. Thus, this is the declarative knowledge that constitutes an important element of creating new routines based on the old ones (Lazaric, 2010, pp. 205-227). The study of routines is about processes of change and stability. It is about the organizational texture of daily activities, interrelations between them, and cognitive constraints and opportunities of transformation. Routines are performed in the organizational, cultural and historical setting. Thus, observation of routines calls for a humanistic field of study. It is important to note that the basic units of analysis are not people operating in organizations, but routines and daily recreated activities that may be changed in-use.

\section{Stability vs. Transformation - a New Twist to an Old Problem}

The main reason for putting the concept of routine in the centre of an old dilemma of stability and change is its contradictory nature. Routines preserve schemas of organizational being, at the same time remaining embedded in human activity. Norbert Elias, a key process sociologist, provided the following metaphor: "The wind is blowing". "We say [then] as if the wind were separate from its blowing, as if a wind could exist which did not blow" (Elias, 1978, pp. 111-112, as cited in Feldman, 2016, p. 29). The categories of wind and blowing are mutually co-existent. In fact, this is the logic behind Martha Feldman's theory of routine as practices (Feldman, 2000). In the world we live in, we can see the effects, i.e. waving flags. People do not "see high and low pressure of the wind". But people can observe ostensive and performative aspects of routines. Both categories are constitutive for routine, but it is possible to differentiate them in empirical studies. Feldman's theory concerns ostensive aspects as typical ways of doing, using and working. It can be applied to technology, decision-making, operating etc. Ostensive aspects are very close to the colloquial meaning of routine and they can be represented in written manuals and procedures, often referred to in the literature as SOP (standard operating procedures). Ostensive aspects are institutionalized in the formal structure of the organization. Performative aspects refer to the changeability of routines. As they are located in-use, they are supposed to impose a new form on the ostensive ones. Performative aspects occur within the daily reproduction of routines, provided that people use alertness and reflexivity in ordinarily performed activities (Feldman, 2000; Pentland \& Feldman, 2003).

Change of recreated routines may be deliberate or spontaneous and unplanned. The market change creates opportunities for enterprises. However, as Simpson and Lorino (2016, p. 55) assume, routines are context-dependent, so they should not be "theorized as either purely individual or purely organizational endeavors". By bringing organizational routines closer to the institutional and market context, one sees whether entrepreneurs and managers are more willing to change or not. To put it simply, the more turbulent the environment is, the more radical routine transformations become. Thus, as liter- 
ature searchers show, there is a plethora of works that focus on observing routines put under industry pressures (Orlikowski, 2000; Wenting, 2009).

Pentland and Ju Jung (2016) propose a framework for the crucial elements of rapid change of organizational routines. They adapted the concept of narrative network by Pentland and Feldman (2007). The concept illustrates schemas (practice patterns) of using a technology. There were "nods" incorporated into the framework that were meant to provide information on who does what. Pentland and Ju Jung furnished this basic framework with elements such as:

1. Actions (what).

2. Actants (who).

3. Narrative Network (pathways for possible routines).

4. Recombination and repetition.

5. New routines.

Actions form the active tissue of what the processes are about. Actants are people or machines that recreate fragmented processes. Actions and actants are "narrative fragments(...) in that story" (Pentland \& Ju Jung, 2016, p. 104). The narrative network is the place where ostensive and performative aspects of routines collide. There are many possibilities (pathways) for acting. They can mix and produce a new processual order (Pentland \& Ju Jung, 2016, pp. 103-110). I think that the conceptual framework of recombination and repetition of pathways by Pentland and Ju Jung (2016) could be divided into two possible types of routine reproduction. One could be based on slowly "emerging" patterns of actions, and the other on the radical or advert change connected with what has been institutionalized up to a given time. The added value of this conception would be the exploration of differences in the way practice evolves.

Schatzki (1996) denotes three fundamental notions of practice. The first one promotes the idea of a practicing as a process of gradual learning or ability to do something strictly by "working at and carrying it out" (Schatzki, 1996, p. 89). That concept can be associated with such examples as practicing the piano. In the second view practice is perceived as "nexus of doings and sayings" that is dispersed in time and space (Schatzki, 1996, p. 89). In order to brighten up this understanding, Schatzki uses such examples as: "voting practices, industrial or market practices, recreational practices, cooking practices etc." (Schatzki, 1996, p. 89). Practice then is a widespread schema of action. Individuals know what to do in order to achieve results. Their activities are guided through widely known instructions or principles. Whereas this view of practice emphasize its casual character, the third conceptualization puts forth performing and actual activity into the understanding of the notion (Schatzki, 1996, p. 89). Practice comes into being when it is performed. This is the basis of constituting and transforming of social structures and institutions. In that sense routines are designated as recursive elements of everyday human actions.

However, in colloquial language routine is still a pejorative term. Elaborating on the Weickian logic, evolutionary economists have made a dynamic sense of this notion (Weick, 1979). Thus, the practice theory put processual brackets around the notion of routine. Routines are locus of the organizational life. They are the carriers of practice, as they contain written or implied rules, norms, patterned schemas of acting, obeyed order of individual roles, and the way resources are deployed. Simultaneously, they are the carriers of change forming a basis for transformation. This process may have path- 
dependent character as well as a radical way of deviating from what was cultivated. Routines are twofold categories and, as Gherardi said, they can "constitute a good or beautiful practice". If they are sustained, it may be assumed that there is some internal logic behind their reproduction (Gherardi, 2012, pp. 2-3).

\section{MATERIAL AND METHODS}

The article presents results of a comparative case study. The aim of the study was to grasp the context and micro-aspects of everyday practice. Thus, the methodological choices made included interviews and non-participant observation. The enterprises operate in creative and textile-apparel industries. Sample selection was purposive and its aim was to compare cases in terms of different routine reproduction processes. The cases were supposed to be compared, thus the interviews were semi-structured. However, some significant topics were brought up spontaneously by the collaborators (interviewees). The interviews were recorded, transcribed and supplemented with notes. Additional notes were taken during the observation of everyday practices and organizational entourage. Collaborators were the owners of Alfa and Beta respectively. In the case of Alfa also a co-owner and a worker took part in the interviews. As a result of the study it was possible to show diverse routine reproduction processes. The framework of Pentland and Ju Jung (2016) was partly used to trace key categories of the phenomena observed.

\section{RESULTS AND DISCUSSION}

\section{Everyday Practice as Loci of Organizational Persistence and Transformation}

The Alfa enterprise has operated in the denim industry for over ten years and it is located in Łódź. It manufactures finished products for domestic and foreign customers. Their core products are jeans, however, it is possible for them to produce other denim clothes as well as furniture covers. The enterprise has a qualified staff and modern machines. Alfa has a wide spectrum of cooperators and customers (see Patora-Wysocka, 2016).

The Beta company is a young and not yet renowned brand from the creative industry located in the WI-MA zone in Łódź. At the moment, its core product is print on textile. The vision of the product is unique, as it involves implementing photographs on a transparent material. The enterprise consists of only one person (owner). The owner is a young woman whose educational background ranges from medicine and industrial design to film scenography. Beta sometimes provides services of designing and producing clothes. The future plan includes jewellery design.

Employing fragmentarily the concept of Pentland and Ju Jung (2016), one sees that actions and actants in the case of Alfa form "narrative fragments" of daily routine patterns in the denim apparel market (Table 1). They operate within two schemas of reproduced practice: the first one consists in delivering finished products, while the other one in sewing services using the fabrics provided. The fabric is usually already pre-shrunk. The capabilities of the Alfa enterprise involve cutting, sewing, organizing the outside pre-shrinkage process, collecting the products, and finishing them. One can get the impression that these activities take place in an almost sequential way. The activities are of repetitive character. 
Table 1. Actions and actants in Alfa

\begin{tabular}{|c|c|}
\hline $\begin{array}{l}\text { Actions and } \\
\text { Actants }\end{array}$ & Opinion \\
\hline $\begin{array}{l}\text { Actions } \\
\text { (examples of daily } \\
\text { action patterns in } \\
\text { the case of Alfa. } \\
\text { Alfa operates in } \\
\text { the denim apparel } \\
\text { industry) } \\
\end{array}$ & $\begin{array}{l}\text { "(...) in fact, there are two methods: we either produce them as finished products, } \\
\text { which means that we buy fabrics, we sew, we launder, I mean we have them laun- } \\
\text { dered because we don't have our own laundry, so we just give them to a partner } \\
\text { laundry, we preshrink them and then they are sold as finished products, or the cus- } \\
\text { tomer provides us with fabrics and we only sew them." } \\
\text { "(...) There is fabric, we buy fabric, it's generally already fixed, we cut it and sew, and } \\
\text { we give them to be pre-shrunk. Then the products return to us and we finish them." }\end{array}$ \\
\hline $\begin{array}{l}\text { Actants } \\
\text { (There are at least: } \\
\text { 1. Machines and } \\
\text { seamstresses who } \\
\text { can use them, } \\
\text { 2. Partner laun- } \\
\text { dries, } \\
\text { 3. Regular business } \\
\text { partners - orderers } \\
\text { 4. Top designers) }\end{array}$ & $\begin{array}{l}\text { "(...) It's not exactly an automatic machine, but it's a machine that attaches waistbands to } \\
\text { trousers. You can sew them manually, so seamstresses can press them down with their } \\
\text { hands, but you can do it using those special rollers, as they are called, and then such a } \\
\text { waistband is really even across and, most of all, this is much quicker, because manually, } \\
\text { let's say, how many waistbands can you attach? Seven an hour? And the machine can sew } \\
\text { for example, forty an hour, so it saves a lot of time." } \\
\text { "(...) we give them to a partner laundry (...)." } \\
\text { "(...) in fact, the first one we had, we've been cooperating for a number of years now, } \\
\text { and the first company was Delta company, which now operates under the Zeta brand." } \\
\text { Comments on some of the designers: “(...) well, they make a fuss about everything } \\
\text { they can because they simply don't know, that's it. That's why they wear it with } \\
\text { other clothes, those more elegant ones, while it's not really the point, you know, } \\
\text { jeans have their own world following their own rules." }\end{array}$ \\
\hline
\end{tabular}

Source: own study.

Actants are parts of all routine schemas (Table 1). In the case of Alfa there is no point in assessing the priority of one actant over another. Actants and actions are mutually constitutive. Machines and people who operate them are inseparable categories of a daily life in the organization. Actants are also present in the local environment of the enterprise. These actants are crucial for a continuum of daily routine reproduction (laundry and regular co-operators). However, there are also important factors that stand for defining recombined ways of patterned actions when it comes to top designers. Alfa has seized the opportunity to create a product with designers. However, the owner recalls it as a tough time full of problems in terms of communication and reciprocal understanding. Nonetheless, one should bear in mind that the 'top designers' actant is an anchor for the nod of making unique denim clothes different from the ones produced on a daily basis.

The institutionalized schema of everyday practice reproduction was radically recombined (Table 2). The core pathway forked into two separate ways: the traditional one, which adheres to the production of denim clothes, and a completely new branch of jeans furniture covers. Alfa jumped at the opportunity to render untypical services for a foreign customer spontaneously. The owner of Alfa recalls that situation as a complete novelty: "Well, frankly speaking... we didn't have a clue how to do it". Using Pentland and Ju Jung terminology, the "narrative fragments (...) of actants and actions" collided and mixed to create a new pathway of doing the practice (Pentland \& Ju Jung, 2016, p. 104). Alfa succeeded and therefore it extended the scope of its services. However, a new actant appeared, i.e. a new customer. This narrative fragment - a new actanat and spontaneous (re)action of Alfa - is developing a node: "Now they found some customer from Russia, who ordered a lot of this from them (...)". Therefore, new practice becomes institutionalized. 
Table 2. New practice institutionalization through radical routine recombination in Alfa

\begin{tabular}{|l|l|}
\hline $\begin{array}{l}\text { Routine reproduction } \\
\text { and new practice }\end{array}$ & \multicolumn{1}{c|}{ Opinion } \\
\hline $\begin{array}{l}\text { Radical change of } \\
\text { routines } \\
\text { (new opportunity, } \\
\text { spontaneity and novel- } \\
\text { ty of activity) }\end{array}$ & $\begin{array}{l}\text { "(Now) we make jeans sofas, I mean covers, and we cooperate with a company } \\
\text { manufacturing furniture, and we simply sew such covers for the sofas and then } \\
\text { they put it on the frame, and you can buy a jeans sofa, right? (...) Yes, yes, they } \\
\text { found us through fabric suppliers, you know? They went to a fabric wholesale } \\
\text { company, they asked someone... and this person recommended us." } \\
\text { "(...) Well, frankly speaking... we didn't have a clue how to do it, I mean... The first time. } \\
\text { They were completely different, some structures, huge... and then you just put it on.. }\end{array}$ \\
\hline $\begin{array}{l}\text { New practice institu- } \\
\text { tionalization } \\
\text { (radical recombination } \\
\text { of routines resulting in } \\
\text { new schemas of action) }\end{array}$ & $\begin{array}{l}\text { "This year they went to some fair because we manufactured a lot... Then there } \\
\text { was something like that, I mean we produced for them all the time (...). Now they } \\
\text { found some customer from Russia, who ordered a lot of this from them, so we had } \\
\text { a good beginning of the year with them, really good. We all thought for some time } \\
\text { that everyone got bored with this, but surprisingly a new market appeared." }\end{array}$ \\
\hline
\end{tabular}

Source: based on Patora-Wysocka (2016, pp. 113-126).

Table 3. Actions and actants in Beta

\begin{tabular}{|c|c|}
\hline Actions and Actants & Opinion \\
\hline $\begin{array}{l}\text { Actions } \\
\text { (examples of daily } \\
\text { action patterns in the } \\
\text { case of Beta. Beta } \\
\text { operates in the crea- } \\
\text { tive industry: nowa- } \\
\text { days, the owner mostly } \\
\text { deals with artistic } \\
\text { textile printing) }\end{array}$ & $\begin{array}{l}\text { "(...) I started [in relation to the short film tutored by prof. J.Gajos in Lodz Film School] } \\
\text { playing with printed textiles, as I based the whole set on transparent printed textiles. } \\
\text { (...) [I'm making] paintings, I mean I'm printing on canvas, but I do everything } \\
\text { using the printing technique." } \\
\text { "(...) it's as if photography has always accompanied me more like a hobby, for } \\
\text { many years, so... I started as if combining them, you know? Well, I use photos } \\
\text { for all kinds of photo collages, I just make them and then I print. And so (...) } \\
\text { paintings, all these things you saw there, curtains, other things, those are } \\
\text { actually some old works of mine, some of them are even unfinished." } \\
\text { "I've got a number of ideas and in order to do it differently than others I don't } \\
\text { start with the textile, I start with an idea which then sort of evolves because I } \\
\text { add textile to it, the whole design evolves, so in the end it's something com- } \\
\text { pletely different (...) but at the moment I think that, unfortunately, for a longer } \\
\text { period of time l'll be doing this only when ordered." }\end{array}$ \\
\hline $\begin{array}{l}\text { Actants } \\
\text { (There are at least: } \\
\text { 1. A3 printer; } \\
\text { 2. Press; } \\
\text { 3. Printing shop; } \\
\text { 4. Seamstresses; } \\
\text { 5. Website; } \\
\text { 6. PC Computer.) }\end{array}$ & $\begin{array}{l}\text { "I have a printer but it's only an A3 printer, and that's it, and a press. And it all looks } \\
\text { like that: up to the A3 format, which means that I can do these small things you can } \\
\text { see here on my own, right? But if I need larger textiles, I have to outsource. I simply } \\
\text { order them in a printing shop, and they print it on exactly the textile I give them, } \\
\text { and in this case I can get it in any format I want, because this is a meter sixty, just } \\
\text { like the length of the roll, right? The width. And they'll print as much as I want." } \\
\text { "(...) I have those two seamstresses I trust who just sew what I need (...)." } \\
\text { A comment on showing designs on the Internet: "There will be (...) } \\
\text { designs on my website." }\end{array}$ \\
\hline
\end{tabular}

Source: own study.

Narrative network in the case of Beta is grounded in print on textiles (Table 3). However, this is a unique printing technique based on photography. There is a diverse texture of actions and actants. The owner of the enterprise is a talented and creative person. She demonstrates many abilities that form the basis for recreating routine patterns. Artefacts and other actants extend the performative aspects of possible routines. And this is partly the way the daily entrepreneurial life is going: "I start with an idea which then sort of evolves because I add textile to it, the whole design evolves, so in the end it's something 
completely different". Paradoxically, the creative way of following the practice is a routine schema. At first, one only sees creative chaos. However, activities stem from goals and business logic, and then they evolve in order to achieve even better results. There is an order of routine reproduction. The owner refers to: 1 . Proven ways of accomplishing products: "if I need larger textiles, I have to outsource. I simply order them in a printing shop", 2. Known partners: "seamstresses I trust", 3. Dissemination of information about the product in the same way: "there will be (...) designs on my website".

Table 4. In search of practice: emergent routine reproduction in Beta

\begin{tabular}{|c|c|}
\hline $\begin{array}{l}\text { Routine reproduction } \\
\text { and new practice }\end{array}$ & Opinion \\
\hline $\begin{array}{l}\text { Emergent routine repro- } \\
\text { duction } \\
\text { (a wide array of routines } \\
\text { and dynamic capabilities } \\
\text { are the bases for emerg- } \\
\text { ing new practice path- } \\
\text { ways) }\end{array}$ & $\begin{array}{l}\text { A: fragment concerning the production of clothes: } \\
\text { ZP-W: "So you're going to suggest a pattern? And the customer will propose } \\
\text { a design, right?" } \\
\text { B: “I mean no, I offer a specific item, right? For example, I don't know, a } \\
\text { dress, and it's complete, the way it looks, but you can, for example, come to } \\
\text { me and then I measure you, me or my seamstress, and depending on this, } \\
\text { because, you know, not everyone looks good in everything, right? You like } \\
\text { the dress but I have some education in this field and know how to change it, } \\
\text { so, I don't know, I shorten it or make it a bit longer, and this is how clothes } \\
\text { are as if adjusted to each person. So, in fact, there's only a minimal chance } \\
\text { that two identical items will be created, right? They are all based on the } \\
\text { same design but there is also this freedom, the design can be changed a bit, } \\
\text { it's all about talking to customers and finding out what they really expect." }\end{array}$ \\
\hline $\begin{array}{l}\text { Searching for practice } \\
\text { (mixing routines, actants } \\
\text { and actions may result in } \\
\text { new practice institution- } \\
\text { alization in the future) }\end{array}$ & $\begin{array}{l}\text { "You had some questions concerning, for example, fashion, well, I'm not } \\
\text { dealing with fashion at the moment (...)." } \\
\text { "(...) But l'd like to make some things connected with jewellery, for example, } \\
\text { and so on." }\end{array}$ \\
\hline
\end{tabular}

Source: own study.

The repetition of ostensive routines stimulates the performative ones (Table 4). The network has many nodes of actions and actants. They are supported by dynamic capabilities and openness to searching for actions of a new kind. A young brand in the creative environment recognizes new possibilities. However, they are not institutionalized yet. There are no grounded schemas of acting besides the core practice of printing on textiles. The case of Beta exemplifies emergent routine reproduction that may be referred to as a starting point for practice institutionalization.

\section{CONCLUSIONS}

Business world is characterized by widespread change and temporality of knowing of what should be done. This concerns market, technology, culture, and institutional order. I believe that paying attention to the daily practice, practitioners, context and situations as well as resources and material tools makes it possible to understand organizational change. It is of significance as far as practice is located in past and future activities of an organization. The research presented in this study illustrates how entrepreneurs respond to everyday phenomena that co-create their business reality. In fact, there are plenty of 
unplanned situations in the day-to-day organizational life. Using them as the basic context for research means in fact observing the fundamentals of managerial and organizational processes. It turns out then that the way of acting may be of twofold nature: radical and spontaneous or evolution-like and emergent. In this respect, the research introduces the processual and micro-ontological approach into the field of management. However, it tackled only one of the problems present in the management and organization theory, i.e. change management. I think that the field of practice theory is open to more issues, such as innovation and technology, strategic management, internationalization, marketing, work studies, conflict management, organizational culture etc. The practice turn in management may be perceived as a promising approach that does not stand in opposition to the dominant strand, but rather offers a complementary perspective.

\section{REFERENCES}

Beck, A.T. (1976). Cognitive Therapy and the Emotional Disorders. New York, NY: New American Library.

Feldman, M.S. (2000). Organizational Routines as a Source of Continuous Change. Organization Science, 11 (6), 611-629.

Feldman, M.S., \& Pentland, B.T. (2003). Reconceptualizing Organizational Routines as a Source of Flexibility and Change. Administrative Science Quarterly, 48, 94-118.

Feldman, M.S. (2016). Routines as Process: Past, Present, and Future. In J. Howard-Grenville, C. Rerup, A. Langley \& H. Tsoukas (Eds.). Organizational Routines: How They are Created, Maintained, and Changed (pp. 23-46). Oxford: Oxford University Press.

Howard-Grenville, J., Rerup, C., Langley, A. \& Tsoukas, H. (Eds.). (2016). Introduction: Advancing a Process Perspective on Routines by Zooming Out and Zooming. In J. Howard-Grenville, C., Rerup, A., Langley and H., Tsoukas (Eds.). Organizational Routines: How They are Created, Maintained, and Changed (pp. 1-22). Oxford: Oxford University Press.

Howard-Grenville, J. (2005). The Persistence of Flexible Organizational Routines - The Role of Agency and Organizational Context. Organization Science, 16 (6), 618-636.

Gherardi, S. (2012). How to conduct a practice-based study. Northampton: Edward Elgar.

Gherardi, S. (2015). To start practice theorizing anew: The contribution of the concepts of agencement and formativeness. Organization, 1-19.

Guzman, G. (2013). The grey textures of practice and knowledge: review and framework. European Business Review, 25 (5), 429-452.

Heidegger, M. (1962). Being and time. Oxford: Blackwell.

Hernes, T. (2014). A Process Theory of Organization. Oxford: Oxford University Press.

Kociatkiewicz, J., Kostera, M. (2013). Zarządzanie humanistyczne. Zarys programu. Problemy Zarzqdzania, 11, 4 (44), 9-19.

Lazaric, N. (2010). Routines and routinization: an exploration of some micro-cognitive foundations. In M.C. Becker (Ed.), Handbook of Organizational Routines (pp. 205-227). Cheltenham, Northampton: Edward Elgar.

Nelson, R., \& Winter, S. (1982). An Evolutionary Theory of Economic Change. Cambridge: Harvard University Press.

Orlikowski, W. (2000). Using Technology and Constituting Structures: A Practice Lens for Studying Technology in Organizations. Organization Science, 11 (4), 404-428. 
Parmigiani, A., \& Howard-Grenville, J. (2011). Routines Revisited: Exploring the Capabilities and Practice Perspectives. The Academy of Management Annals, 5 (1), 413-453.

Patora-Wysocka, Z. (2016). The Institutionalisation of Practice: A processual Perspective on Value Co-creation. Economics and Business Review, 2 (16), 113-126.

Pentland, B.T., \& Jung Ju, E. (2016). Evolutionary and Revolutionary Change in Path-Dependent Patterns of Action. In J. Howard-Grenville, C. Rerup, A. Langley, H. Tsoukas (Eds.). Organizational Routines: How They are Created, Maintained, and Changed (pp. 96-116). Oxford: Oxford University Press.

Pentland, B.T., \& Feldman, M. (2007). Narrative networks: Patterns of Technology and Organization. Organization Science, 18 (5), 781-95.

Salvato, C., \& Rerup, C. (2011). Beyond Collective Entities: Multilevel Research on Organizational Routines and Capabilities. Journal of Management, 37 (2), 468-90.

Schatzki, T.R. (1996). Social Practices. A Wittgensteinian Approach to Human Activity and the Social. Cambridge: Cambridge University Press.

Sewell, W.H. Jr (1992). A Theory of Structure: Duality, Agency, and Transformation. American Journal of Sociology, 98 (1), 1-29.

Simpson, B., \& Lorino, P. (2016). Re-Viewing Routines through a Pragmatist Lens. In J. HowardGrenville, C. Rerup, A. Langley, H. Tsoukas (Eds.). Organizational Routines: How They are Created, Maintained, and Changed (pp. 47-70). Oxford: Oxford University Press.

Weick, K.E. (1979). The Social Psychology of Organising. Reading: Addison-Wesley.

Wenting, R. (2009). The inheritance of organizational routines and the emergence of a firm genealogy in the fashion design industry. In M. C. Becker, N. Lazaric (Eds.). Organizational Routines: Advancing Empirical Research. Cheltenham, Northampton: Edward Elgar, 103-128. 


\section{Author}

\section{Zofia Patora-Wysocka}

Assistant Professor of University of Social Sciences. Her research interests include organizational change management, international entrepreneurship, organization and management theory, organizational behaviour.

Correspondence to: dr Zofia Patora-Wysocka, Społeczna Akademia Nauk, Katedra Zarządzania, ul. Sienkiewicza 9 90-113 Łódź, Poland, e-mail: zpatora-wysocka@spoleczna.pl

\section{Acknowledgements and Financial Disclosure}

The article came into being within the project no. DEC-2011/03/D/HS4/01651 entitled "Internationalization as a factor initiating change in the enterprise" financed by the National Science Centre and conducted by the University of Social Sciences in the years 2012-2016.

The author would like to thank the anonymous referees for their useful comments, which allowed to increase the value of this article.

\section{Copyright and License}

This article is published under the terms of the Creative Commons Attribution - NoDerivs (CC BY- ND 4.0) License http://creativecommons.org/licenses/by-nd/4.0/

Published by the Centre for Strategic and International Entrepreneurship - Krakow, Poland 